\title{
Water Quality Data Analysis for Kanhan River
}

\author{
SNEHAL K. KAMBLE*, P.B. NAGARNAIK and R.R. SHRIVASTAVA \\ Department of Civil Engineering, G.H. Raisoni College of Engineering, Nagpur- 440016, India. \\ http://dx.doi.org/10.12944/CWE.9.2.28
}

(Received: May 13, 2014; Accepted: June 24, 2014)

\begin{abstract}
The Kanhan River originates from the high lands of Chindawara District and flows in south east direction for about $160 \mathrm{kms}$ before it enters the state of Maharashtra near Raiwari village in Saoner Taluka of Nagpur District. Nagpur city is presently getting water for from two major sources namely Kanhan River (Head work located near village Juni Kamptee) \&Pench Dam (through Right Bank Canal with Lifting Point at Mahadula at $48.5 \mathrm{Km}$ of canal). Samples were collected from seven major locations along the stretch of river. The samples were subjected to physicochemical analysis and performed during summer, rainy and winter seasons. The physicochemical parameters of the water samples includes $\mathrm{pH}$, temperature, turbidity, conductivity (EC), suspended solids (SS), total dissolved solids (TDS), total solids (TS), dissolved oxygen (DO) and biological oxygen demand (BOD). The water quality index (WQI) is used to evaluate the quality of the river water for drinking in rainy, winter and summer season. The study was carried out to examine the change in the quality of the river water due to addition of human waste discharge, industrial waste discharge into river body and the seasonal variation in the physicochemical properties of the river.
\end{abstract}

Key words: Water pollution, Kanhan River, Physicochemical analysis, Water Quality Index.

\section{INTRODUCTION}

Water is the prime requirement for the existence of life and thus it has been man's endeavor for the time immemorial to utilize the available resources. Water is a ubiquitous chemical substance that is composed of hydrogen and oxygen and is vital for all known forms of life. In typical usage, water refers only to its liquid from or state, but the substance also has a solid state, ice, and a gaseous state, water vapor or stream. Watercovers $71 \%$ of the earth's surface. On earth, it is found mostly in oceans and other large water bodies, with $1.6 \%$ of water below ground in aquifers and $0.001 \%$ in the air as vapor, clouds (formed of solid and liquid water particles suspended in air), and precipitation. Oceans hold $97 \%$ of surface water, glaciers and polar ice caps $2.4 \%$ and other land surface water such as rivers, lakes and ponds $0.6 \%$. A very small amount of the earth's water is contained within biological bodies and manufactured products (Mahesh Kumar. Akkaraboyina et al., 2012).
Surface water pollution with chemical, physical and biological contaminants by anthropogenic activities is of great environmental attention all over the world. Surface water systems mainly mean the waters naturally open to atmosphere, for example rivers, lakes and reservoirs water. Rivers play an important role in a watershed for carrying off municipal and industrial wastewater and run-off from farm land, and are one of the most susceptible water bodies to pollutants. The constant discharges of domestic and industrial wastewater and seasonal surface run-off due to the climate all have a strong effect on the river discharge and water quality. However, rivers are the main water sources for domestic, industrial and agricultural irrigation purposes in a region, river water quality is one of important factors directly concerning with health of human and living beings. Pollution of a river first affects its chemical quality and then systematically destroys the community disrupting the delicate food web. Diverse uses of the rivers are seriously impaired due to pollution and even the polluters like 
industry suffer due to increased pollution of the rivers. River pollution has several dimensions and effective monitoring and control of river pollution requires the expertise from various disciplines. Pollution of river is a global problem. In India it is reported that about $70 \%$ of the available water is polluted. The chief source of pollution is identified as sewage constituting 84 to 92 percent of the waste water. Industrial waste water comprised 8 to 16 percent. Therefore, it is imperative and important to have reliable information on characteristics of water quality for effective pollution control and water resource management (Xiaoyun Fan et al., 2010).

The River is the one major natural resource which serves as a need for the human beings. The River Kanhan originates from the high lands of Chindawara district near village Tarai in M.P. and flows in south east direction for about $160 \mathrm{kms}$ before it enters the state of Maharashtra near Raiwari village in Saoner Taluka of district Nagpur. During its course it passes through Saoner, Nagpur, Kamptee and Mouda Tahsils of Nagpur District covering a distance of about $80 \mathrm{kms}$, before it ultimately joins wainganga as a right hand tributary near Jawahar Nagar ordnance Factory in district Bhandara. The Kanhan River is a tributary of Wainganga River with a confluence at Ambhora. Under the WaingangaWardha-Painganga River basin, the department mentions Pench River as a tributary of Wainganga River. It says "Pench River meets the Wainganga River". In fact, Pench River is a tributary of the Kanhan and meets it at Bina village, upstream from the Nagpur Municipal Corporation's (NMC) Kanhan water treatment plant. Then, the Kanhan flows for over $40 \mathrm{~km}$ before meeting the Wainganga River.

River Kanhan serves as a major drinking source for Nagpur district. It has been use as a major river water source for drinking and domestic purposes like washing clothes, bathing etc. from past several years. Kanhan water supply scheme was commissioned in four phases during the year. Under this scheme, two intake wells and two dry wells in Kanhan River are constructed. Raw water is pumped to conventional Treatment Plant of 109 MLD capacity. The two intake wells located approximately $14 \mathrm{~km}$ from Nagpur city and $300 \mathrm{~m}$ downstream of the confluence of the River Kolar and the Kanhan was constructed in year 1940. In 1956 a barrage was constructed across Kanhan River about $500 \mathrm{~m}$ upstream Kanhan head works with a storage capacity of $7.82 \mathrm{Mm}^{3}$. The average monthly discharge of the River Kanhan is found maximum in the month of September i.e.760.78 cumecs and minimum in the month of June i.e. 48.96 cumecs. Water supply \& respective present drawel as shown in the table 1:

Two big thermal power plants, NTPC's Mouda plant and Mahagenco's Khaparkheda plant, are situated near Kanhan River. It is reported that the fly ash and other waste from power plants is being released into Kanhan River through its tributaries. Pollution of River first affects its chemical quality and then destroys the community. Pollution of River is a global problem. In India it is reported that about 70\% of the available water is polluted. The chief source of pollution is identified as sewage constituting 84 to $92 \%$ of the waste water. Industrial waste water comprised $8-16 \%$.

Kamptee is located at latitude $21^{\circ} 223^{\prime}$ north, longitude $79^{\circ} 2^{\prime}$ west. According to the 2001 census, it has an area of 40,706 hectares. National Highway No.7 passes through it. There are three bridges over the Kanhan River. One is a railway bridge, and the other, older bridge, is a road N.H.7 and a newer one small road that goes to Old Kamptee. There is one big water filter plant which supplies water to the larger area of Nagpur city. Kamptee was founded in 1821 when the British established a military cantonment on the banks of the Kanhan River. Kamptee was previously named Camp-T for its geographical shape.

The over-exploitation of limited resources has not only caused a perceptible decline in the water table, but also resulted in the enormous increase of pollutants concentration. The ever growing population exerts a great pressure on this resource. The never ending growth of population and ill-planned exploitation of the water resource created a situation, where the very survival of man has become endangered. The concern for protecting the quality and overuse of earth's natural resources has been increasing in recent years all over the world. The global awareness and concern for the 
environment have paved way for the installation of various policies to control and preventenvironmental pollution.

The objectives of the present paper are (1) to determine the seasonal variation in the river in rainy, winter and summer season and (2)To study the change in the quality of the river water due to addition of human waste discharge, industrial waste discharge into river body.

Accurate and timely information on the quality of water is necessary to shape a sound public policy and to implement the water quality improvement programmes efficiently. One of the most effective ways to communicate information on water quality trends is with indices. Water quality index (WQI) is commonly used for the detection and evaluation of water pollution and may be defined as "arating reflecting the composite influence of different quality parameters on the overall quality of water." (Mahesh Kumar.Akkaraboyina et al., 2012).

\section{MATERIALS AND METHODS}

\section{Study area description}

The study is carried out to determine the water quality of Kanhan River for the three season viz. rainy season, winter season and summer season for the period of eight months. Seven major locations along the stretch of the River Kanhan were selected for monthly analysis as shown in the Fig. 1and the details of the sations are given in table 2. Station 1 (confluence of Kanhan and Pench), station 2 (confluence of Kanhan and Kolar), station 3 and 4 is the wastewater discharge points at the upstream and downstream side of the point. The wastewater coming from the nearby residents is being discharged directly into the river through a drain without any treatment. Station 5 is the intake well located near the water treatment plant. Station 6 and 7 is the upstream and downstream side Kanhan.

\section{Experiment}

The samples were subjected to the physicochemical analysis which includes parameters such temperature, $\mathrm{pH}$, turbidity, conductivity, total dissolved solids (TDS), suspended solids (SS), total solids (TS), dissolved oxygen (DO), biochemical oxygen demand (BOD). Water samples were collected twice in every month to get the cumulative readings for a month from the water quality monitoring stations. Grab sampling was generally applied during the sampling. The samples were taken in BOD bottles and plastic canes and brought to the laboratory with necessary precautions. All samples were labeled properly and analyzed by standard methods. Parameter like temperature of River water was recorded on site. DO and BOD were performed in the laboratory by standard titrimetric method.

\section{Water Quality Index Calculation}

Essentially, a WQI is a compilation of a number of parameters that can be used to determine the overall quality of a river. The parameters involved in the WQI are dissolved oxygen, $\mathrm{pH}$, turbidity, conductivity, TDS, SS, TS, DO, biochemical BOD. The numerical value is then multiplied by a weighting factor that is relative to the significance of the test to water quality. The sum of the resulting values is added together to arrive at an overall water quality index (Dhirendra Mohan Josh et al., 2009; Tiwari, T.N. et al., 1985).

\section{RESULTS AND DISCUSSION}

The result of the water quality parameters (temperature, $\mathrm{pH}$, turbidity, conductivity, DO, BOD, TS,TDS, SS) collected from seven major location of the river from the month September to April. The observations are recorded. The minimum (a) and maximum (b) values in the rainy season (September), winter season (October to February) and summer season (March and April) are depicted in the graphsbelow (Fig. 2-10).

The above results, values refer to the minimum and maximum value of the water samples collected from the month of September to April i.e. rainy, winter and summer seasons for the physiochemical analysis. The summary of the findings is given below:

\section{Temperature of river water}

The water temperature of the Kanhan River was found minimum in the winter season and maximum in the summer season. The minimum temperature in the rainy season was recorded as $24.5^{\circ} \mathrm{C}$ and $25.5^{\circ} \mathrm{C}$ as maximum. In winter season the temperature ranged from $16.3^{\circ} \mathrm{C}$ to $24.2^{\circ} \mathrm{C}$. The maximum temperature was recorded 
in summer with minimum $33^{\circ} \mathrm{C}$ to maximum $40{ }^{\circ} \mathrm{C}$. The water temperature showed an upward trend from winter season to summer season followed by a downward trend from rainy season onwards. The temperature differed at every sampling station. The high temperature was recorded in the station 3 ( $\mathrm{u} / \mathrm{s}$ of waste water discharge point). Since, the waste water from the residing area resulting from the domestic use is discharged into the water body. The temperature of that particular stretch of river increases, as the temperature of wastewater is slightly high and discharged in the river water continuously in the large quantity. The minimum temperature recorded in stations 2 (confluence of Kanhan and Kolar) and 6 (u/s of Kanhan).

\section{$\mathrm{pH}$}

The $\mathrm{pH}$ of the Kanhan River was slightly alkaline. In rainy season the minimum $\mathrm{pH}$ was observed as 7.9 and maximum 8.3. In winter season the $\mathrm{pH}$ ranged from 8 to 8.8 . In summer season the water becomes more alkaline. The minimum value was 8.5 and maximum 8.8. The $\mathrm{pH}$ is high at station 6 (u/s of Kanhan), as the water is used for domestic purpose from the residents near the river bank for e.g.washing clothes, bathing etc. This makes the water more alkaline due to the domestic use of water.

\section{Turbidity}

The turbidity was lowest during the summer season. In rainy season the turbidity ranged from 100 to 230 NTU. The minimum value in winter season was found as 23.8 NTU and maximum 180 NTU. In summer the turbidity ranged from 21 to 96 NTU. The maximum turbidity was recorded at station $3 \mathrm{u} / \mathrm{s}$ of waste water discharge point), the wastewater is continuously discharged into the river body.

\section{Conductivity}

The conductivity increases considerably from the rainy season and was recorded maximum

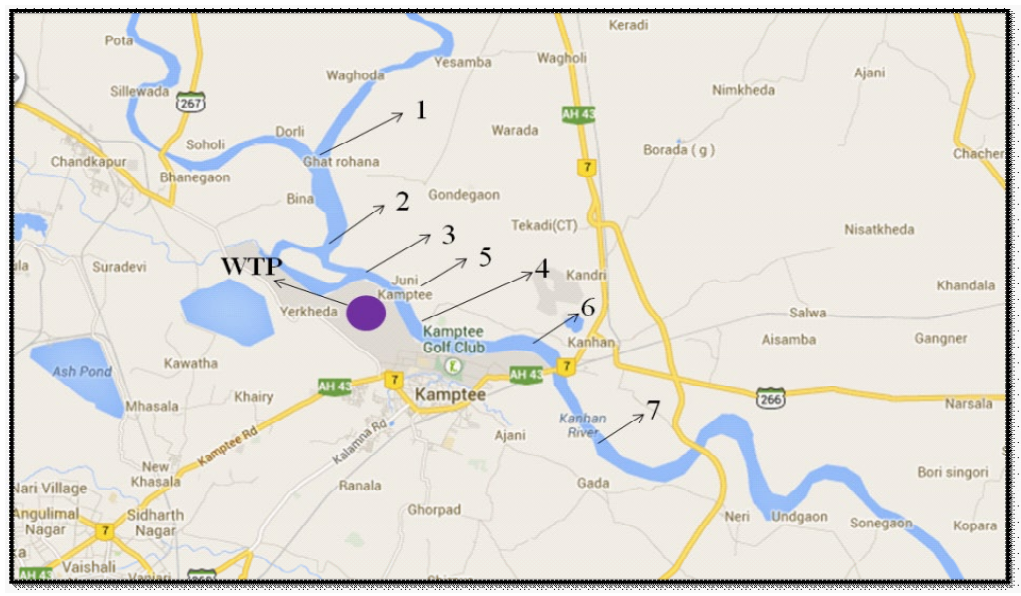

Fig.1: Map showing location of sampling stations

Table 1: Present Annual Raw Water reservation from various sources for city

\begin{tabular}{|c|c|c|c|c|}
\hline \multirow[t]{2}{*}{ Source } & \multicolumn{2}{|c|}{$\begin{array}{c}\text { Annual } \\
\text { reservation }\end{array}$} & \multicolumn{2}{|c|}{$\begin{array}{c}\text { Actual drawel } \\
\text { (as per Biling to NMC) }\end{array}$} \\
\hline & $\mathrm{Mm}^{3} /$ year & MLD & $\mathrm{Mm}^{3} /$ year & MLD \\
\hline Kanhan River & 55.00 & 150.70 & 43.80 & 120 \\
\hline Pench project (PRBC) at Mahadula & $\begin{array}{l}112.00 \\
78.00\end{array}$ & $\begin{array}{l}306.88 \\
213.72\end{array}$ & 143.00 & 400 \\
\hline Gorewada Lake & 5.80 & 16.00 & 6.80 & 20.00 \\
\hline Total & 250.80 & 687.30 & 217.60 & 540.0 \\
\hline
\end{tabular}


Temper ature of river water $\left({ }^{\circ} \mathrm{C}\right)$

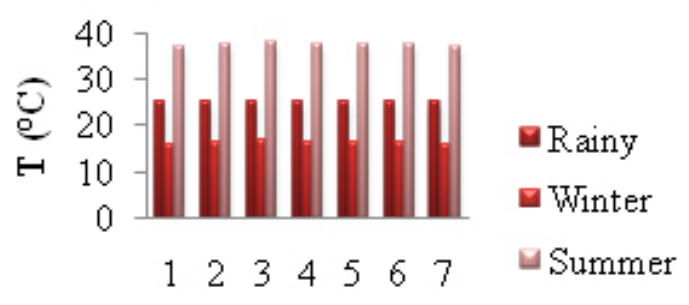

Sampling Stations

Fig: 2 (a)

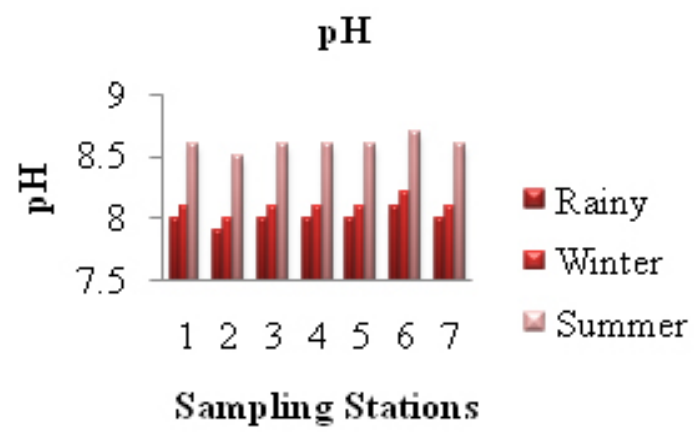

Fig: 3 (a)

Turbidity (NTU)

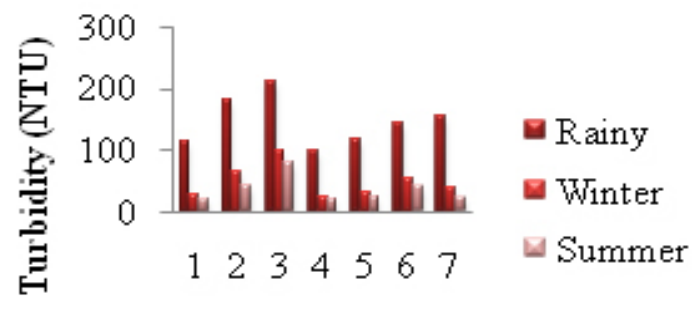

Sampling Stations

Fig: 4 (a)
Temper ature of river water $\left({ }^{\circ} \mathrm{C}\right)$

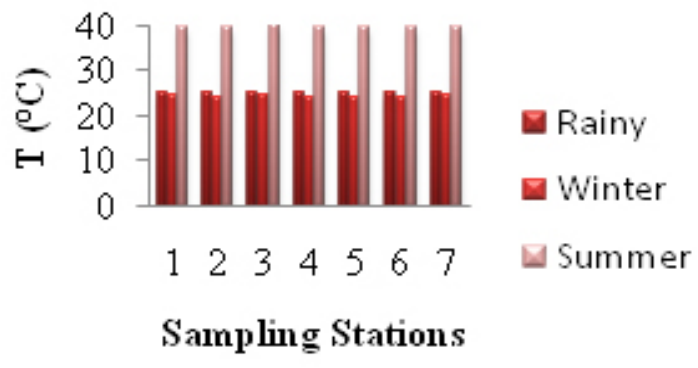

Fig: 2 (b)

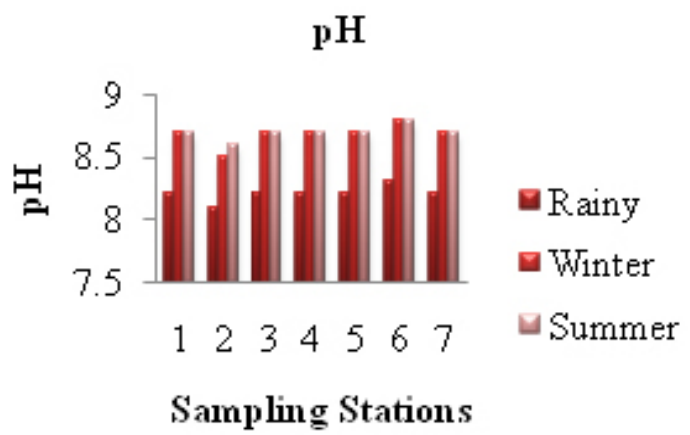

Fig: 3 (b)

Turbidity (NTU)

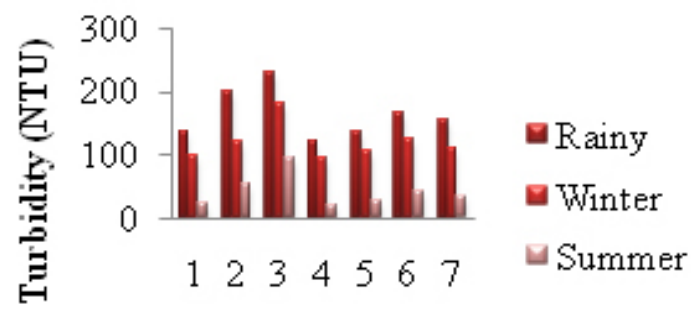

Sampling Stations

Fig: 4 (b)

Table. 2: Sampling stations

\section{Sampling Locations} stations

\section{Distance}

$23.2 \mathrm{kms}$ from Nagpur

$18.6 \mathrm{kms}$ from Bina

Juni Kamptee 13.5 km from Bina

Juni Kamptee $14.5 \mathrm{~km}$ from $\mathrm{u} / \mathrm{s}$ side of waste water

Juni Kamptee $14 \mathrm{~km}$ from Nagpur

$4.5 \mathrm{~km}$ from Juni Kamptee

$5.5 \mathrm{~km}$ from $\mathrm{u} / \mathrm{s}$ side of Kanhan River 
Conductivity (umho/cm)
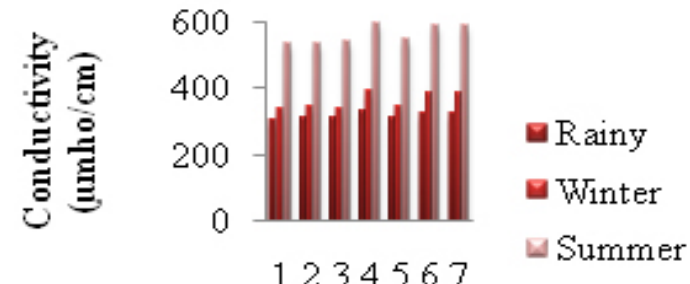

Sampling Stations

Fig: 5 (a)

Dissolved Oxygen (mg/1)

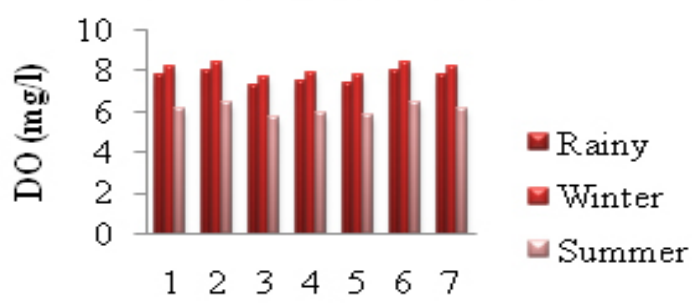

Sampling Stations

Fig: 6 (a)

\section{Biochemical Oxygen Demand (mg/)}

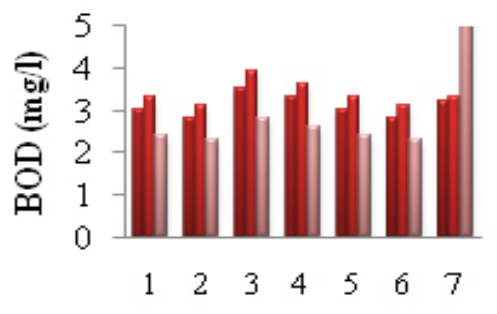

Sampling Stations

Fig: 7 (a)

\section{Total Solids (mo/l)}

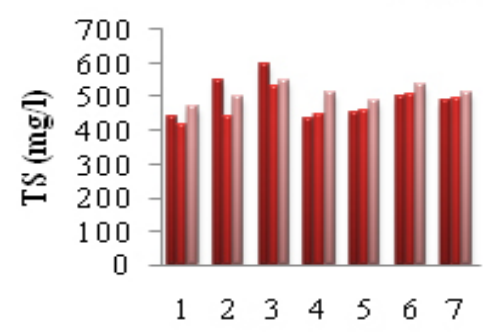

Sampling Stations

Fig: 8 (a) $\square$ Rainy

$\square$ Winter

$\square$ Summer

$\square$ Rainy

$\square$ Winter

$\square$ Summer
Conductivity (umho/cm)

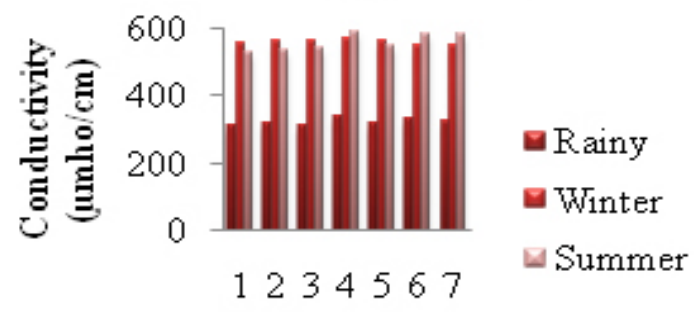

Sampling Stations

Fig: 5 (b)

\section{Dissolved Oxygen (mg/)}

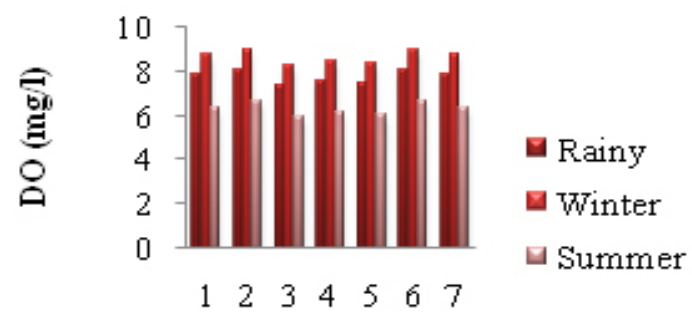

Sampling Stations

Fig: 6 (b)

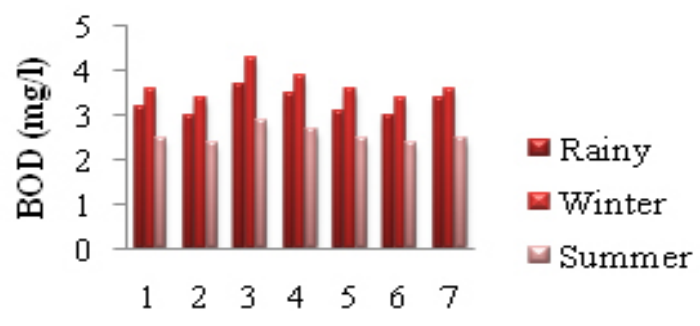

Sampling Stations

Fig: 7 (b)

Total Solids (mg/l)

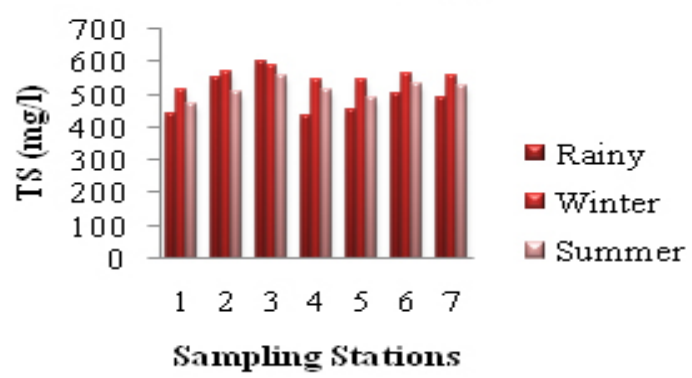

Fig: 8 (b) 


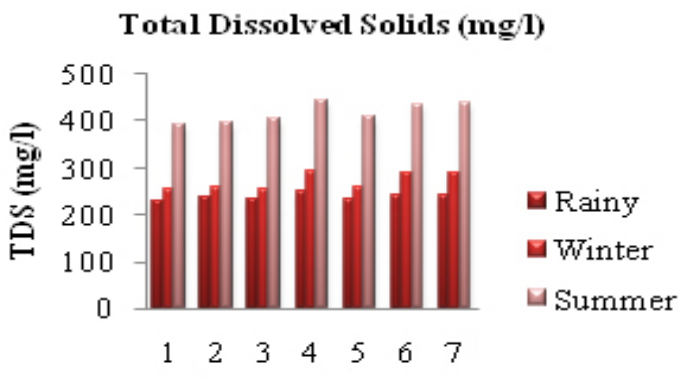

Sampling Stations

Fig: 9 (a)

Suspended Solids (mg/1)

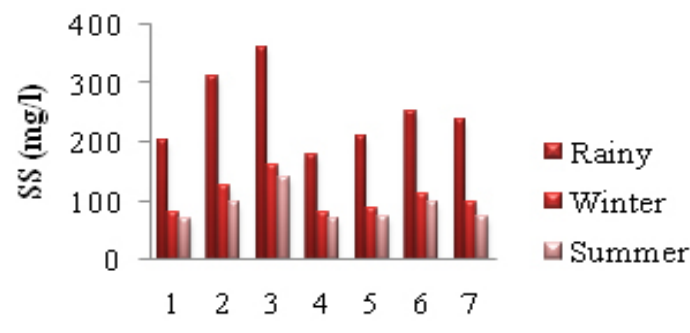

Sampling Stations

Fig: 10 (a)
Total Dissolved Solids (mg/)

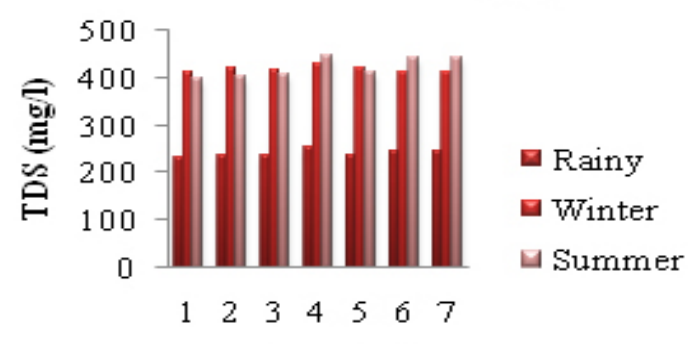

Sampling Stations

Fig: 9 (b)

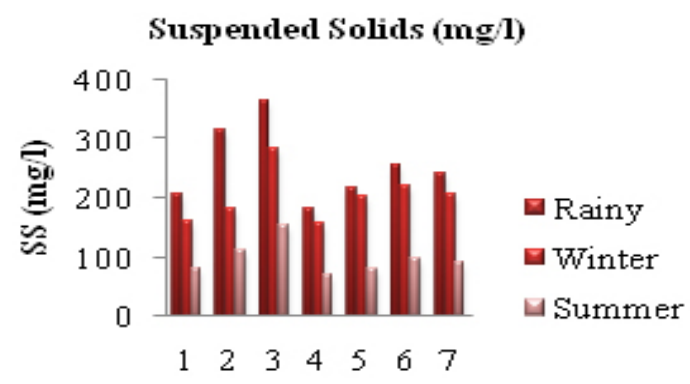

Sampling Stations

Fig: 10 (b) in the summer. The minimum conductivity $306 \mu \mathrm{mho} /$ $\mathrm{cm}$ and maximum $338 \mu \mathrm{mho} / \mathrm{cm}$ was found in the rainy season. In winter season the conductivity raises to minimum $338 \mu \mathrm{mho} / \mathrm{cm}$ to maximum conductivity $570 \mu \mathrm{mho} / \mathrm{cm}$. The highest conductivity $531 \mu \mathrm{mho} /$ $\mathrm{cm}$ to $595 \mu \mathrm{mho} / \mathrm{cm}$ was observed in summer season.Sampling station $4(\mathrm{~d} / \mathrm{s}$ of waste water discharge point) has maximum conductivity in every season and minimum at sampling station $3(\mathrm{~d} / \mathrm{s}$ of waste water discharge point).

\section{Dissolved oxygen}

In rainy season the DO ranged from $7.3 \mathrm{mg} / \mathrm{l}$ to $8.1 \mathrm{mg} / \mathrm{l}$. The higher concentration of dissolved oxygen during winter season was probably due to low water temperature. The minimum DO $7.7 \mathrm{mg} / \mathrm{l}$ and maximum $9 \mathrm{mg} / \mathrm{l}$ was observed during winter season. In summer season the DO slightly decrease and found minimum $5.7 \mathrm{mg} / \mathrm{l}$ to maximum $6.6 \mathrm{mg} / \mathrm{l}$. The DO varies with the temperature. DO was maximum at station 2 (confluence of Kanhan and Kolar) and 6 (d/s of Kanhan) and minimum at station 3 (u/s wastewater discharge point). The temperature at station 3 was recorded high and low in the stations 2 .

\section{Biochemical Oxygen Demand}

The minimum BOD $2.8 \mathrm{mg} / \mathrm{l}$ and maximum $3.7 \mathrm{mg} / \mathrm{l}$ was observed during the rainy season. In winter season $3.1 \mathrm{mg} / \mathrm{l}$ minimum and maximum 4.3 $\mathrm{mg} / \mathrm{l}$ BOD was observed. The BOD decreases in summer season and ranged from $2.3 \mathrm{mg} / \mathrm{l}$ to 2.9 $\mathrm{mg} / \mathrm{l}$. The maximum BOD was observed at station 3 (u/s wastewater discharge point) and minimum at station 2 (confluence of Kanhan and Kolar). The wastewater discharged at station 3 contents the organic matters. Thus, to oxygen required to decompose organic matter is more at this point.

\section{Total Solids}

The TS was found maximum in rainy season and ranged from $436.03 \mathrm{mg} / \mathrm{l}$ to 600.64 $\mathrm{mg} / \mathrm{l}$. The minimum TS $415.85 \mathrm{mg} / \mathrm{l}$ and maximum $587.9 \mathrm{mg} / \mathrm{l}$ was observed in the winter season. In summer season the TS ranged minimum 469.49 $\mathrm{mg} / \mathrm{l}$ and $558.4 \mathrm{mg} / \mathrm{l}$ maximum. The maximum TS 
was observed at station $3(\mathrm{u} / \mathrm{s}$ wastewater discharge point) due to the high concentration of suspended solids and minimum at station 1 (confluence of Kanhan and Pench).

\section{Total Dissolved Solids}

The TDS was found maximum in rainy season and ranged from $232.1 \mathrm{mg} / \mathrm{l}$ to $253.5 \mathrm{mg} / \mathrm{l}$. The minimum TDS $253.5 \mathrm{mg} / \mathrm{l}$ and maximum 427.5 $\mathrm{mg} / \mathrm{l}$ was observed in the winter season. In summer season the TS ranged minimum $394.5 \mathrm{mg} / \mathrm{l}$ and $446.25 \mathrm{mg} / \mathrm{l}$ maximum. At station $4(\mathrm{~d} / \mathrm{s}$ of waste water discharge point) the TDS concentration is maximum with the minimum at the station 1 (confluence of Kanhan and Pench).

\section{Suspended Solids}

The SS was foundmaximum in rainy season and ranged from $177.82 \mathrm{mg} / \mathrm{l}$ to $365.14 \mathrm{mg} / \mathrm{l}$. The minimum SS $78.88 \mathrm{mg} / \mathrm{l}$ and maximum $282.28 \mathrm{mg} / \mathrm{l}$ was observed in the winter season. In summer season the TS ranged minimum $68.78 \mathrm{mg} / \mathrm{l}$ and $154.9 \mathrm{mg} / \mathrm{l}$ maximum. The SS was observed high at station 3 (u/s of waste water discharge point) and minimum at station $4(\mathrm{~d} / \mathrm{s}$ of waste water discharge point).

Water quality index represents the integrated effects of the relevant water quality variables. For Knahan River water, the rating of WQI of water samples was calculated. The values of WQI indicated that the water quality rating, the quality of river water was rated bad in rainy (32.58) and summer (46.17) season with the WQI range 25-50. While the WQI rages form 50-70, with the medium water quality rating in winter season (46.17). The average WQI for all the seasons ranged from 50-70 resulting having medium (54.84) quality rating.

\section{CONCLUSION}

Based on the analysis and observations it could be seen that the concentration of the physiochemical parameters is high in the summer season compared to rainy and winter season. This is due to the low water level that results in less availability of dilution factor.The quality of water as calculated by WQI was found moderate for drinking purpose in winter season and rated bad in rainy and summer season.Concentration of the parameters like $\mathrm{pH}, \mathrm{BOD}$, turbidity, DO, and TDS is found maximum. These parameters was found above the prescribed standards may affect the water treatment plant when processed for drinking water treatment. Parameters like TS and TDS were found within the standards limits.

\section{ACKNOWLEDGMENT}

I would like to express my sincere respect and gratitude towards my guide and co-guidefor their encouragement and constant support for water quality studies. I would also like to thank the GHRCE laboratory and supportive staffs for providing essential chemicals and facilities and for the presentwork.

\section{REFERENCES}

1. Mahesh Kumar.Akkaraboyina et al., International Journal of Engineering Research and Development, 2(3), 29-34 (2012).

2. Xiaoyun Fan et al., Procedia Environmental Sciences 2: 1220-1234 (2010).

3. Dhirendra Mohan Josh et al., Rasayan Journal Chem. 2: 195-203 (2009).

4. Tiwari, T.N. et al., International Journal Environ Prot. 5: 276 (1985).

5. Mohd Ekhwan, T. et al., International Journal of Agriculture and Crop Sciences, 4 (2): 33-39 (2012).

6. Bindu N. Lohani et al., Journal Environ.
Eng.113: 186-195 (1987).

7. CCME 2001. Canadian water quality guidelines for the protection of aquatic life: Canadian Water Quality Index 1.0 Technical Report. In Canadian environmental quality guidelines. 1999. Winnipeg.

8. Calculation of the Drinking Water Quality Index-Government of Newfoundland and Labrador (Department of Environment and Conservation).

9. M. Meybeck et al., "Chapter 6- River", Water Quality Assessments - A Guide to Use of Biota, Sediments and Water in Environmental 
Monitoring-Second Edition.

10. Petra Judova et al., Limnologica 35: 160-168 (2005).

11. Volume I, Part B: Surveillance- CHEEPO.

12. "Water Qualitry Index" Investigation 12: 8598.

13. S.L. Dwivedi et al., Indian Journal Enivronmental Protection, 27 (11): 10361038 (2007).
14. Seca Gandaseca et al., American Journal of Environmental Sciences 7 (3): 269-275 (2011).

15. Y. Avasn Maruthi et al., Asian Journal of Chemistry, 16: 122-130 (2004).

16. Yoshiaki Tsuzuki et al., Journal of Environmental Sciences 22(6),892-897 (2010). 